\title{
Physiological requirements for wheat ideotypes in response to drought threat
}

\author{
Krystyna Rybka $^{1}$ Zygmunt Nita ${ }^{2}$
}

Received: 14 July 2014/Revised: 28 March 2015/Accepted: 13 April 2015/Published online: 25 April 2015

(C) The Author(s) 2015. This article is published with open access at Springerlink.com

\begin{abstract}
Understanding the theoretical aspects of crops drought resistance is fundamental for maintaining the present rate of yield growth which is the key factor in the prospect of increasing world population. Achievements in plant physiology and biochemistry uncovered many metabolic pathways and defined indicators of plant resistance to environmental stresses. Genetic research contributed to discoveries of gene regulation in stress tolerance. As the result of fast development of genetics, phenomics became a hold-up of further functional research. In this paper, problems related to phenotype requirements for crops cultivation in drought threatened areas will be presented against the background of achievements in metabolomics and genomics. Theoretical speculations of Blum on crop water use efficiency will be examined against the results of Sirius simulation with HadCM3 climate projections and against practical phenological requirements for present crops.
\end{abstract}

Keywords Drought - Phenomics - Water use - Wheat · Triticum aestivum

Communicated by A. K. Kononowicz.

Krystyna Rybka

k.rybka@ihar.edu.pl

Zygmunt Nita

z_nita@hr-strzelce.pl

1 Biochemistry and Plant Physiology Department, Plant Breeding and Acclimatization Institute IHAR-PIB, Radzików, 05-870 Błonie, Poland

2 Hodowla Roślin Strzelce Sp. z o.o. Grupa IHAR, ul. Główna 20, 99-307 Strzelce, Poland

\section{Introduction}

The increase of crop yields in the last five decades resulted, to a significant degree, from the green revolution, which introduced dwarf wheat varieties and a steady improvement of their harvest index (HI) achieved by the reduction of stem length (Anioł 2010; Borlaug 2007). In the 1990s, a considerable yield stagnancy was observed in countries with highly developed agriculture and intensive management, while, in some years, the yield production dropped significantly below the prognostic values, e.g., in Great Britain where yield per hectare neared $10 \mathrm{t}$ (Fig. 1) both in breeding experiments and agricultural holdings. Wheat yield at the $>8 \mathrm{t} / \mathrm{ha}$ level is primarily the result of $\mathrm{HI}$ optimization, the observed stagnancy means reaching this value $(\approx 0.64)$ (Jaggard et al. 2010).

While in Poland, the mean yield of winter wheat increased from $1.28 \mathrm{t} /$ ha in 1960 to $4.43 \mathrm{t} /$ ha in 2013 (Fig. 1) (Oleksiak 2013), it was interrupted by substantial reductions caused, among others, by droughts which, in 2006, occurred during stem formation and grain filling stages, critical for wheat yield (Craufurd et al. 2013). In Poland, yield stagnation has not yet been observed since yields in agricultural holdings are about half the value of yields achieved in breeding experiments. Yielding potential of Polish wheat varieties is very high, e.g., in the Agro-Industrial Complex Kietrz located in areas of optimal climate and rich soils $(50.0833 \mathrm{~N}, 18.0000 \mathrm{E})$, winter wheat cultivars, Bamberka and Muszelka, under intensive farming, produce a yield of $110 \mathrm{dt} / \mathrm{ha}$ in an area of over $2000 \mathrm{ha}$. Lower average yield in smaller farms results from lower level of agrotechnology and low inputs in cropping. Bigger farms use, among others, precise administration of fertilizers based on knowledge about mineral content in the soil. Information is fed into a computer in the form of a map of 


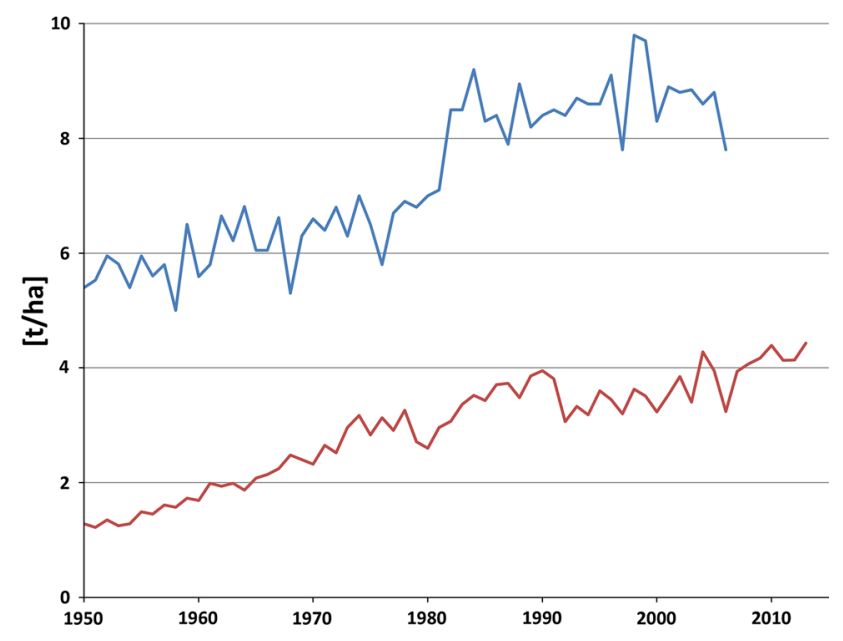

Fig. 1 Wheat yield in Great Britain (blue line) and Poland (brown line) since 1950 (T. Oleksiak, personal communication; Mackay et al. 2011, modified)

soil mineral content and total mineral content that should be evenly dispensed in every square meter of the field. Based on these maps and GPS, precise doses of fertilizers are administered. Furthermore, large farms also apply full plant protection procedures.

Home Grown Cereals Authority (HGCA), the agency of the British Agriculture and Horticulture Development Board (AHDB), financed by agricultural producers with no participation of the government or corporations, indicates the following causes (besides $\mathrm{HI}$ ) of stagnant yields: changing weather conditions, particularly increasing soil water deficit, increasing UV-B radiation, soil compaction and acidification, water draining land improvement systems and costs of cereal seed (Knight et al. 2012).

In this article, attention will be focused on implications of changes in weather conditions for plant breeders. We will review biochemical and physiological indices of plant drought resistance, discuss effective use of water by crop plants as well as modeling of future wheat ideotypes using statistical forecasting.

\section{Agricultural drought phenomenon}

In the climate zone of Central Europe, one of the crucial causes of agricultural drought is variation in precipitation type from continuous to convectional, related to temperature rise (Easterling et al. 2000, Sillmann and Roeckner 2008; Trenberth et al. 2003). Extreme events of rainfall, supplying large amounts of water in a short period of time, has increased and replaced moderate rains and drizzles. This process can be illustrated by a trend line of precipitation values on wet days above the 95th percentile of Gaussian distribution of mean daily precipitation in
Central Europe (Fig. 2). Furthermore, Easterling et al. (1997) compared global weather data and, based on the 1939-1994 period, demonstrated a linear upward trend of days with heavy rains, with the increase rate of $3.9 \%$ per decade, while total precipitation decreased at a rate of $1 \%$ of the annual precipitation/decade for European Russia. In the case of Germany, $6.5 \%$ increase of heavy rains is predicted for every degree of temperature rise (Tomassini and Jacob 2009). Additionally, rainfall use efficiency has been decreasing, since the retention of water from heavy rainfall in the arable layer is less effective (Łabędzki 2006). The agricultural drought in Poland is monitored by the Institute of Soil Science and Plant Cultivation-IUNG (Doroszewski et al. 2012). The country is threatened by drought since the annual freshwater use exceeds $25 \%$ of total resources, while, according to the UN, withdrawal no higher than $20 \%$ guarantees its natural renewal. FAO (2003) indicates that in Europe only Macedonia, Germany, Spain and Bulgaria are at greater risk than Poland. These conditions create two problems: the general one of how to protect freshwater resources and the specific one of what crop phenotypes can assure stable yields in droughtthreatened areas. In our discussion of phenotypic requirements for modern cereal crop varieties, we will focus on wheat, the main grain crop in the European Union, where on average $46 \%$, and specifically in Poland $28 \%$, of the total arable area is used for its cultivation (GUS 2013).

\section{Plant responses to drought on molecular and physiological levels}

Biochemical and physiological studies on drought influence on plants are systematically summarized in review papers (Foyer and Noctor 2009; Jogaiah et al. 2013;

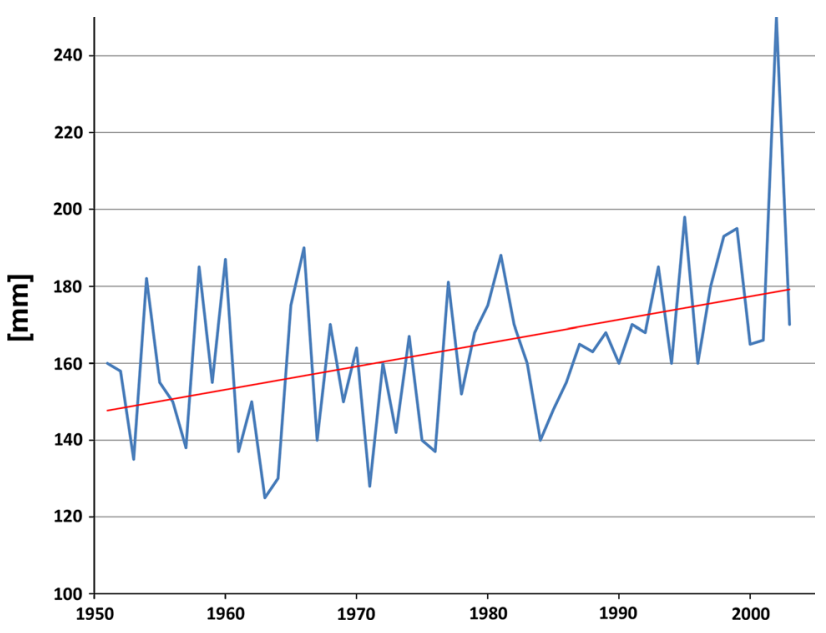

Fig. 2 Trend (straight line) of increasing rainfall rate $(\mathrm{mm})$ above the 95th percentile of mean daily rainfall on wet days in Central Europe (Sillmann and Roeckner 2008, modified) 
Labudda and Azam 2014; Reynolds and Tuberosa 2008). Much research was based on Arabidopsis thaliana as a model organism. Very often, the experiments involved drought treatment under conditions that were definitely different from the field conditions (Claeys et al. 2014; Vadez et al. 2013a).

In the case of higher plants, including crops, the phenomena of dehydration tolerance and dehydration avoidance are types of reactions to water shortage in arable soil. These two responses to drought stress are complementary (Levitt 1972). The terms: "drought stress avoidance and tolerance" are fundamental and relevant to the physiological status of plants in the conditions of water shortage. The term "drought resistance" is a common working phrase used, i.e., by breeders working toward better yielding crops in drought-threatened areas (Blum 2011b).

Water shortage induces dysfunction of plant vital processes leading to the inhibition of growth and development and, in case of long-term water deficit, to tissue decay. It is accompanied by the reduction of water potential and cellular activity, turgor and cell volume reduction, inducing increase of osmoprotectant concentration, changes in macromolecule structure and spatial relationship between cellular compartments accompanied by reduced transpiration and photosynthesis. These processes often result in reduced crop yield which is unacceptable from the economic point of view (Kacperska 2002; Maseda and Ferniez 2006; Richards et al. 2010).

At the biochemical level, dehydration-tolerant plants are characterized by: (1) more effective identification and transduction of signals (including ABA) (Cutler et al. 2010; Pantin et al. 2013); (2) more efficient systems of protein repair or proteolytic removal (Grudkowska and Zagdańska 2004); (3) better protection of cell membranes by osmoprotectants (Iturriaga et al. 2009; Zhang et al. 2009); (4) the existence of LEA proteins (abundant late embryogenesis) interacting primarily with trehalose (Iturriaga 2008; Caramelo and Iusem 2009; Hussain et al. 2011); (5) more stable photosynthesis (Jaleel et al. 2009; Pinheiro and Chaves 2011); (6) more stable mitochondria metabolism (Atkin and Macherel 2009; Zagdańska, 1997); and (7) more stable tissue oxidation-reduction potential sustained by mechanisms inhibiting generation of free radicals as well as by their effective inactivation (Miller et al. 2010).

At the molecular level, drought induces the expression of several genes including those encoding protective metabolites (i.e., LEA proteins, Hsp (Heat shock proteins), proline, glycine betaine); genes for sugar osmoprotectant (mannitol and trehalose) synthesis; genes for enzymes maintaining the correct cell membrane structure, e.g., $\omega-3$ and $\Delta-6$ desaturases; genes encoding protein-modifying enzymes: proteinases and proteases as well as phosphatases; genes for enzymes degrading reactive oxygen species (ROS) molecules and enzymes affecting the cell oxidation-reduction potential: dismutases, catalases, peroxidases and reductases; and cellular transporter genes: aquaporins. Among genes encoding signal transductors, kinase genes and genes for transcription factors encoding proteins from the following families can be found: DREB (dehydration response elements binding), ERF (ethylene responsive transcription factor), WRKY (transcription factors with the conserved amino acid sequence: WRKYGQK), MYB (MYeloBlastosis), bHLH (basic Helix Loop Helix), bZIP (basic Leucine Zipper Domain), NAC (transcription factors of Nam, Ataf1 and Cuc2, genes possessing common domain) and genes encoding zinc finger protein family (Gosal et al. 2009). Regulation of drought-induced modifications of gene expression by RNAi was also studied (Bhatnagar-Mathur et al. 2008). The genes for phytohormone synthesis and phytohormonedependent stress defense signaling such as ABA and gibberellin, jasmonic acid and brassinosteroids were also identified to be engaged in drought resistance regulation (Fleury et al. 2010; Hu and Xiong 2014; Shinozaki and Yamaguchi-Shinozaki 2007; Zhou et al. 2014).

Despite muli-year studies on plant genomes, proteomes and metabolomes, the data regarding mechanisms of plant tolerance to environmental stresses are still insufficient for a complete understanding of the processes determining stress tolerance and consequently for economically successful genetic manipulations (Atkinson and Urwin 2012; Bhatnagar-Mathur et al. 2008; Rybka 2011; Tardieu 2010; Vadez et al. 2013b). Legitimizations for economically viable genetic manipulation are recent results of studies on DREB1A transgenic groundnut (Vadez et al. 2013c). Biochemical theoretical achievements are reflected in practice by detection of higher ABA level in leaves of drought-tolerant near isogenic lines (NILs) of pearl millet (Kholová et al. 2010b) as well as in proof of aquaporin functions in turgor maintenance under high vapor pressure deficit (Vadez et al. 2014). However, the extraction of genetic components of complex qualitative traits is still laborious and expensive, since the diversity of phenotypes resulting from complex interaction between plant and environment is difficult to describe due to the multitude of variables in the 'genotype-environment' interactions (Houle et al. 2010). This brings a new meaning to phenotypes in field observation as well as in the frames of functional genomics and phenomics studies (Araus and Cairns 2014; Chern et al. 2011; Craufurd et al. 2013; Schoppach and Sadok 2012; Vadez et al. 2008).

Recently, Vadez and co-workers (2013b) reviewed aspects of plant water balance and determinants of crop yield under soil water scarcity. Water-capturing process related to root structure and water conservation for growth phases most sensitive to drought are the key factors 
guaranteeing effective crop production in drought-threatened areas. The mechanisms influencing root water uptake and its usage by shoots are highly complex (Passioura 2012). Although cultivars with deeper roots with proper architecture are often considered to be more water stress tolerant, it is not a sufficient selection trait to ensure achieving the breeding goal. Besides positive correlations found between root structure and water extraction, there are some reports showing a poor relation between roots and water uptake among grain crops and legumes (Vadez et al. 2013b). This controversy partially results from technical difficulties concerning root studies as well as non-uniform water availability in the soil. Until new experimental methods are introduced, the non-destructive measurements of water uptake at consecutive growth phases, using new lysimetric methods, seem to be an easier target for studies on relations between water capture and crop yield (Vadez et al. 2008, 2014).

It is postulated that genotype adaptation to water shortage is beneficial if this genotype is able to take advantage of small amounts of water available at critical stages of growth. The grain filling period was confirmed experimentally as the important one (Christopher et al. 2008; Vadez et al. 2013b; Wasson et al. 2012). Ten millimeters of subsoil water absorbed after anthesis by wheat roots, between depths of 1.35 and $1.85 \mathrm{~m}$, would increase the grain yield by $0.62 \mathrm{t} \mathrm{ha}^{-1}$ (Kirkegaard et al. 2007), which constitutes about $25 \%$ of the global average yield of wheat per hectare. Water extraction by roots at later stages of cereal plants growth would be possible, if roots continued to grow till that time, a feature which should be screened in breeding processes. Such an approach to the problem of water uptake by the roots is appropriate only for soil profiles which are sufficiently deep and rich in water. Water extraction at later stages appears to be dependent on water-saving mechanisms at earlier stages of plant growth and on shoot water demand. Since root and shoot growth are under the same genetic control, faster root growth can cause quick exploration of soil water. For this reason, faster rate of root growth should be an important trait for genotypes extracting all soil-available water prior to maturity in climate conditions of short rainfall duration or in areas with deep soil profiles rich in water in deeper layers (Vadez et al. 2013b). Despite the difficulties in testing and correlation with the yield not always being observed, roots seem to be the force of the second green revolution which will increase the crop yield to feed future generations (Gewin 2010).

Water conservation on plant and canopy level is the second most important factor of field water stress tolerance underlined by Vadez and co-authors (2013b). The rate of leaf canopy development and the leaf area at a time close to anthesis are crucial components for determining water usage. Fast canopy development reduces soil transpiration and thereby water loss during the vegetation (Blum 2011b). On the other hand, it was shown that genotypes of legume, such as chickpea, peanut, cowpea as well as sorghum, tolerant to water stress, have smaller leaf canopy at the vegetative stage. Experiment on maize showed leaf size reduction under water pressure deficit and also under low vapor pressure deficit, documenting hydraulic control of leaf development. Comprehension of genetic and interactive environmental determinants of leaf size would be profitable for breeding crops dedicated to specific environments (Vadez et al. 2013b).

Besides the leaf size, leaf conductance also influences water usage. It was demonstrated that chickpea, cowpea and pearl millet under well-watered conditions differ within the genotype in leaf canopy conductance measured by the gravimetric method. The studied genotypes also differed in sensitivity to vapor pressure deficit (ZamanAllah et al. 2011; Belko et al. 2013; Kholová et al. 2010a). The interactions of hormonal and hydraulic signals in control of stomata conductance do not raise doubts (Comstock 2002; Mott 2007). For increasing crop transpiration efficiency genotypes sensitive to vapor pressure deficit, partially closing stomata as the answer to drought and reversing to primary transpiration rate after the rain or irrigation would be appropriate for breeding (Vadez et al. 2013b).

In parallel with adaptive mechanisms, as a result of natural selection or selective breeding, dehydration avoidance systems have been introduced into crop cultivars: (1) temporal coordination of water availability and demand (in Poland-earliness, germination in soil drought conditions); (2) fast germination and tillering to shade the soil; (3) short growing period (plants finish their growth before drought occurrence) or the opposite-long growing period (such plants usually develop deeper root systems); (4) lower leaf permeability due to wax, so that transpiration occurs only through stomata, as evaporation other than through stomata is unproductive for photosynthesis and (5) leaf drying, thus reducing water demand. Biomass accumulation in vegetative cells and allocation of assimilates primarily into grains during the grain filling stage despite soil moisture deficits are also important drought avoidance mechanisms (Zagdańska and Kozdój 1994; Żurek 2004).

Phenotypic assessment is presently a bottleneck in the study of genotype-environment interaction (Yang et al. 2013), e.g., mapping based on 20 populations consisting of 200 lines, out of which 5 single plants are selected, requires 20,000 estimates of a single phenotype trait in one location (White et al. 2012). There is an urgent need for highquality phenotyping (Craufurd et al. 2013) and, hence, the 
development of phenomics, which allows acquiring multiparameter data regarding a complete plant, many phenotypes of one genotype in many environments based on mass and automated measurements in state-of-the-art glasshouses. At the same time, phenotyping based on hyperspectral data collected from fields is being developed (Cabrera-Bosquet et al. 2012; Gnyp et al. 2014; Granier et al. 2006; Lopes et al. 2014). Clearly defined objectives and conditions for statistical algorithms would make the analysis of such huge sets of data feasible (Craufurd et al. 2013; Liu et al. 2010).

\section{Drought and efficient water use by crop plants}

Selection toward higher yielding cultivars has been commonly supported by midday differential canopy temperature measurements, as the marker correlated negatively with the yield (Amani et al. 1996). Following the proof of Blum (2009), on the basis of Passioura equation, the direct proportion of transpiration and biomass production can be evaluated. Since $Y=\mathrm{WU} \times \mathrm{WUE} \times \mathrm{HI}$, where $Y$ is grain yield, WU is water use $\left(\mathrm{dm}^{3}\right)$, WUE is water-use efficiency $\left(\mathrm{kg} \mathrm{dm}^{-3}\right)$ and $\mathrm{HI}$ is harvest index (Reynolds and Tuberosa 2008), the assumption that WUE $=B /$ WU (B-biomass) leads to equation: $Y=B \times$ HI. If $B$ is replaced with de Wit algorithm, $B=\mathrm{mT} / E_{0}$ where $m$ is a crop constant, T is crop transpiration and $E_{0}$ is free water (potential) evaporation. The direct proportion $Y \propto T$ is reached. WUE at the leaf level corresponds to transpiration efficiency (TE; the amount of transpired water per unit of assimilated $\mathrm{CO}_{2}$ ) which is the result of dynamic balance between photosynthetic activity, intra-leaf $\mathrm{CO}_{2}$ concentration and stomata response to environmental stimuli. Carbon isotope discrimination and stomata conductivity have long been used as markers in selection work as well (Fischer et al. 1998). Such a selection resulted in higher yielding genotypes under drought stress (Blum et al. 1982; Izanloo et al. 2008) as well as on sufficiently watered soils (Fischer et al. 1998; Lu et al. 1994; Shimshi and Ephrat 1975). Even though in 1990 it was mentioned that the warmest wheat cultivars under well-watered conditions had the highest relative yields when exposed to deficit irrigation (Pinter et al. 1990), the negative correlation between canopy temperature and crop yield has been used as a marker in breeding work (Feng et al. 2009). This tactic may have partly arisen from the negative correlation between canopy temperature and crop disease resistance, with the main biotic cause of chlorophyll decay entailing the reduction of $\mathrm{CO}_{2}$ fixation and the increase of leaf surface temperature (Eyal and Blum 1989). Selection for higher yielding genotypes on the basis of high stomatal conductance over time led to unintended promotion of genotypes with lower efficiency of transpiration and water use (Blum 2009; Tardieu 2012).

In the face of water scarcity, the enhancement of crop production should be achieved primarily by capturing all available soil water by the end of the crop cycle and its complete utilization in carbon assimilation, which would ensure the effective use of water (EUW) (Blum 2009). It is possible for crops to select toward effective use of water, since there is a high variation in transpiration in breeding materials. Fish and Earl (2009) determined the coefficients of variation for transpiration of several species with results: $30 \%$ for cotton, $41 \%$ for peanut, $25 \%$ for sorghum, 32 and $17 \%$ for wheat, $18 \%$ for soybean and $11 \%$ for pea. Kemanian et al. (2005) indicated an almost twofold range of TE values for barley varieties and threefold range for wheat varieties. Also, TE coefficient of variation for maize, a C4 plant which uses water more "economically" by nature, is $>50 \%$ (Du et al. 2009). Research data (Bacławska-Krzemińska 1973; Fish and Earl 2009; Strebeyko 1973) have shown the potential of intra-species variation which can be explored to target water-effective breeds.

Breeding crops efficiently using water is being driven by noticeable shift toward statistically modeled decision making. That shift is manifested by the change of perspective from searching for alleles or traits conferring drought tolerance to asking the question whether a given allele could ensure a positive influence on yield over a sufficiently long time in a given area, how it will be affected by the climate change as well as what is the trade-off between risk avoidance and maintained performance (Tardieu 2010). Such an approach is closely related to the regionalization of crop production, since most frequent soil types and weather conditions must be characterized for a particular region to search for traits most effective at the present and in the future, ensuring the best water utilization for yield production (Kholová et al. 2013). The pioneering grain sorghum breeding program run by Cooper in Australia resulted in model construction combining phenotypic data and parental diversity described by RFLP markers with potential use in the selection of hybrid breeding (Jordan et al. 2003). His work at Pioneer Hi-Bred Inc., based on genetic, physiological and environmental knowledge, resulted in maize DH lines with improved drought tolerance (Messina et al. 2011). Studies on pearl millet enabled the identification of terminal drought-tolerant genotypes with transpiration rate lower than sensitive forms in hydrologically optimal conditions (Kholová et al. 2010a, b). Two mechanisms of water saving in well-watered conditions were postulated, related to biochemical (ABA) and physical (hydraulic) signals transduction (Kholová et al. 2010b). For post-rainy season sorghum in India, the model was constructed to narrow the search of 
(rabi) sorghum-adaptive traits and management practices under severe drought (Kholová et al. 2013, 2014).

Since crop adaptation to drought conditions mainly concerns the plant water economy (Blum 2011a; Vadez et al. 2013a), success in breeding cultivars for droughtthreatened areas "requires an understanding of plant traits affecting yield under water deficit as well as an understanding of their mutual and environmental interactions. Given that the phenotypic evaluation of germplasm/ breeding material is limited by the number of locations and years of testing, crop simulation modeling becomes a powerful tool for navigating the complexity of biological systems, for predicting the effects on yield and for determining the probability of success of specific traits or trait combinations across water stress scenarios" (Vadez et al. 2013b).

\section{Crop phenotype modeling as a support tool for breeding}

The genetic/biochemical determinants of plant responses to drought under climate change scenarios with increasing temperatures and transitions of precipitation character are forecasted to affect strongly the crop production (Jogaiah et al. 2013; Lobell and Tebaldi 2014; Marcińska et al. 2013). To meet the growing food demand, new approaches in methods of plant breeding are being developed, among which decision-support methods based on empirical (statistical) or mechanistic modeling are becoming increasingly important (Thakur 1991; Passioura 1996; Tardieu 2010). For agronomic purposes, the empirical models are largely constructed on the basis of statistical fitting of the yield to weather data, while mechanistic models utilize measured parameters essential for describing the phases of crop life cycle: vegetative and reproductive growth at target conditions. Modeling is advanced, i.e., for calculation of transpiration at the canopy level, projection of the crop yield for the current year or designing new cropping systems (Tardieu 2010). Gene networks and biochemical pathways are recently being constructed on the bases of metabolomic, transcriptomic and genomic data (YonekuraSakakibara et al. 2013), since the future crop ideotyping is less advanced (Tardieu 2010). It is believed that modeling and crop ideotyping can link phenotype complexity with genomic data in a way useful for breeding purposes (Hammer et al. 2004, 2010).

Since there are several crop models used around the world with different levels of uncertainties in simulated results, in October 2010 the global Agricultural Models Intercomparison and Improvement Project (AgMIP) was established for identification and prioritization of crop agronomic strategies for future climate scenarios as well as economic circumstances (Anonymous 2014). Cultivarspecific groups were formed for wheat, maize, rice, sugarcane, potato, sorghum, millet, peanut and soybean studies. It was decided that the wheat studies would comprise 27 models listed by Rosenzweig et al. (2013, 2014), among which better known are: CERES developed at Michigan State University (Ritchie et al. 1998), EPIC constructed by USDA, AquaCrop by FAO (Gassman et al. 2004) and APSIM developed by CSIRO in Australia (Hammer et al. 2010). Here, the model Sirius, included also in AgMIP comparisons, developed in the UK and exploited by Rothamsed Research (Brooks et al. 2001), which works well for temperate climates (Semenov and Stratonovitch 2013; Semenov et al. 2014; Asseng et al. 2013), will be discussed. It includes the HadCM3 package for climate projection (Porter and Semenov 2005). In 2010, the genetic (evolutionary) algorithm with self-adaptation capacity (GA-SA) was added to the Sirius model to optimize wheat ideotypes for target environments (Semenov and Stratonovitch 2013). In general, the genetic algorithms are inspired by the Darwin's theory of natural selection producing optimal phenotypes for specific and strictly determined environments from random and unidirectional mutations in the organism's genome. The statistical effectiveness and quality of combinatorial optimization of genetic algorithms depend highly on how well scoring function and goals are defined. The simulation process, which itself is quite complicated, depends on many different factors that have significant influence on the final result. Algorithm construction, definition of scoring function and information coding determine the model quality. In models destined for plant breeding, yield is the final measure. The main events affecting its height are: atmospheric conditions and environmental stresses. In repetitive calculations, optimized parameters, providing the best target achievement, are chosen and, as in the natural selection process, used in ensuing computation cycle (Koza et al. 2003). In the simplest cases, the algorithm does not require any changes during the simulation process; however, reference experiments confirming the effectiveness of the calculation method are carried out in most cases (Wolf et al. 1996).

The Sirius mechanistic model of wheat response to environmental variation supported by GA-SA self-adaptation genetic algorithm was calibrated for modern wheat cultivars and the simulation accuracy was experimentally verified in a large spectrum of environmental conditions in Europe, New Zealand, Australia and the USA (Semenov and Stratonovitch 2013). It calculates the biomass production based on data concerning photosynthetically active radiation (PAR) and grain growth. Leaf area index (LAI) is calculated using thermal time sub-model. Both LAI and radiation-use efficiency form the basis for forecasting 
water and nitrogen deficiencies in plant development. Phenological development is modeled based on the rate of the main stem leaf appearance and their final number, with daylength and vernalization impact. As the Sirius model developers say: "despite there being no calculation of tiller dynamics or grain number, the model accurately simulated the behavior of crops exposed to a wide range of conditions" (Jamieson et al. 1998). The modeling group concluded that "the accurate prediction of phenological development and LAI is much more important for grain yield prediction than are the components of yield" (tiller dynamics or grain number). "Although grain population is not a necessary step in yield calculation in Sirius, the model proved useful in investigating the effects of stress in setting grain number. The analysis showed that the influence of stress on partitioning of biomass to the ear during pre-anthesis ear growth was much more important in determining grain number than was the effect on biomass accumulation during the same phase" (Jamieson et al. 1998).

In statistical modeling of wheat ideotypes toward 2050s using Sirius, five parameter groups covering nine physiological traits were used. The range of each parameter was estimated and calibrated based on experiments performed worldwide (Semenov et al. 2014).

1. Parameters characterizing photosynthesis: light conversion efficiency $(L)$, dimensionless unit within the 1-1.10 range. Modeling indicated the possibility of increased carbon assimilation efficiency by $10 \%$ at the present level of Rubisco activity and lower $\mathrm{CO}_{2}$ concentration in the atmosphere in the future.

2. Parameters describing plant phenology-timing and duration of key developmental events: phyllochron $(\mathrm{Ph})$, trait of growth defined by time elapsing between the visual appearance of the first leaf and next ones within the range of $70-140\left({ }^{\circ} \mathrm{C}\right.$ days) (McMaster 2005); daylength response $(\mathrm{Pp})$ within the range of 0.05-0.7 (number of leaves $\times \mathrm{h}^{-1}$ daylength); duration of grain filling (Gf) within the range of $500-900\left({ }^{\circ} \mathrm{C}\right.$ days). Modifications of duration and time of each growth stage depending on seasonal changes of quality and intensity of solar radiation and on seasonal water accessibility are crucial for crop yield (Akkaya et al. 2006; Richards 2006). Sirius optimizes these factors according to weather scenarios. Earlier flowering and longer grain filling duration can positively affect yield.

3. Parameters characterizing canopy: ratio of leaf area to soil area $(A)$ within the range of $0.003-0.01$ ( $\mathrm{m}^{2}$ leaf/ $\mathrm{m}^{2}$ soil) and 'stay green' parameter $(S)$ with values of 1-2 (dimensionless). By modeling, leaf area index (LAI) is also changed which affects light use efficiency and transpiration and hence growth rate. Delaying leaf senescence prolongs assimilation period and consequently increases yield.

4. Parameters characterizing drought tolerance: response of photosynthesis to water stress (Wsa) within the range of $0.1-0.21$ (dimensionless) and acceleration of leaf senescence (WSS) with the values of 1.2-1.9 (dimensionless). Both biomass production related to photosynthesis efficiency and leaf senescence are proportional to drought tolerance, thus increasing drought resistance and, consequently, positively affect parameters determining yield.

5. Parameters characterizing root water uptake: rate of water uptake $(\mathrm{Ru})$ within the range of $1-7(\%)$. This parameter is difficult to measure; however, it was observed that in drought conditions, slower root water uptake can ultimately accomplish longer periods of water availability in soil and, in fact, higher yield in water deficit conditions (Manschadi et al. 2006).

The objective of wheat ideotypes modeling was to estimate those relative values of physiological parameters that would ensure yield maximization till 2050 at each of the selected sites in Europe, characterized by different climate conditions (Table 1). Climate projections were generated by the HadCM3 global climate model (Meehl et al. 2007 after Semenov et al. 2014). In case of each site, the same type of soil (Hafren) with available water capacity of $177 \mathrm{~mm}$ was fixed. Already at the first iterations with the use of the GA-SA algorithm searching for local maxima in multi-parameter bases, parameters of duration of grain filling (Gf), maximum leaf area $(A)$ and 'stay green' $(S)$ reached their maximum possible values, i.e., their relative values were 1 . After adopting these maximum values for future wheat ideotypes, in the next iteration cycles, the convergence of parameters characterizing plant phenology was observed: phyllochron $(\mathrm{Ph})$ for a large area from $37.4 \mathrm{~N}$ to $49.5 \mathrm{~N}$ and $-5.9 \mathrm{~W}$ to $21.6 \mathrm{E}$ and responses to photoperiod (Pp) at sites of Tylstrup and Debrecen as well as Warsaw and Mannheim. Parameters describing plant response to drought stress such as accelerated leaf senescence (WSS) and response of photosynthesis (WSA) showed convergence only at those sites where water deficits could have significant impact on grain yield. WSS indicated convergence for Warsaw, Rothamsted and from Debrecen to Seville; WSA for Rothamsted, Mannheim and Debrecen. The values of these parameters were zero, which means that both accelerated leaf senescence (WSS) and disturbed photosynthesis caused by water stress are undesired characteristics. In case of Warsaw, Rothamsted and Mannheim, the model projected the need to maintain root water uptake parameter at the level of $94 \%$ of the initially assumed maximum value, which indicates the importance of this trait of the wheat ideotype modeled by Sirius for 
Table 1 Normalized coefficients ( $0-1$ range) of wheat phenotypes for local scale climate scenarios for 2050. $G f$ duration of grain filling, $A$ maximum area of flag leaf, $S$ 'stay green', $R u$ rate of water uptake, Wsa response of photosynthesis to water stress, Wss maximum acceleration of leaf senescence, $P p$ daylength response/photoperiod, $P h$ phyllochron, $L$ light conversion efficiency (Semenov et al. 2014, modified)

\begin{tabular}{|c|c|c|c|c|c|c|c|c|c|c|}
\hline \multirow[t]{2}{*}{ Site } & \multirow{2}{*}{$\begin{array}{l}\text { GPS } \\
\text { data }\end{array}$} & \multirow{2}{*}{$\begin{array}{l}\text { Annual } \\
\text { rainfall } \\
(\mathrm{mm})\end{array}$} & \multicolumn{8}{|c|}{ Normalized coefficients } \\
\hline & & & $\begin{array}{l}\text { Duration } \\
\text { of grain } \\
\text { filling } \\
\text { Gf-1 }\end{array}$ & $\begin{array}{l}\text { Maximum } \\
\text { area of flag } \\
\text { leaf } \\
\text { A-2 }\end{array}$ & $\begin{array}{l}\text { 'Stay } \\
\text { green' } \\
\text { S-3 }\end{array}$ & $\begin{array}{l}\text { Phyllochron } \\
\mathrm{Ph}\end{array}$ & $\begin{array}{l}\text { Daylength } \\
\text { response } \\
\mathrm{Pp}\end{array}$ & $\begin{array}{l}\text { Maximum } \\
\text { acceleration of } \\
\text { leaf senescence } \\
\text { Wss }\end{array}$ & $\begin{array}{l}\text { Response of } \\
\text { photoperiod to } \\
\text { water stress } \\
\text { Wsa }\end{array}$ & $\begin{array}{l}\text { Rate of } \\
\text { water } \\
\text { uptake } \\
\mathrm{Ru}\end{array}$ \\
\hline $\begin{array}{l}\text { Tylstrup, } \\
\text { Denmark }\end{array}$ & $\begin{array}{l}9.9^{\circ} / \\
57.2^{\circ}\end{array}$ & 668 & 1 & 1 & 1 & 0.51 & 0.39 & 0 & 0.28 & 0.59 \\
\hline $\begin{array}{l}\text { Edinburgh, } \\
\text { UK }\end{array}$ & $\begin{array}{r}-3.3^{\circ} / \\
55.9^{\circ}\end{array}$ & 650 & 1 & 1 & 1 & 0.28 & 0.07 & 0.48 & 0.15 & 0.06 \\
\hline $\begin{array}{l}\text { Warsaw, } \\
\text { Poland }\end{array}$ & $\begin{array}{r}21.1^{\circ} \% \\
52.1^{\circ}\end{array}$ & 458 & 1 & 1 & 1 & 0.49 & 0.47 & 0 & 0.37 & 0.94 \\
\hline $\begin{array}{l}\text { Wageningen, } \\
\text { Holland }\end{array}$ & $\begin{array}{l}5.7^{\circ} \% \\
52.0^{\circ}\end{array}$ & 765 & 1 & 1 & 1 & 0.71 & 0 & 0.93 & 0.18 & 0.69 \\
\hline $\begin{array}{l}\text { Rothamsted, } \\
\text { UK }\end{array}$ & $\begin{array}{r}-0.4^{\circ} / \\
51.8^{\circ}\end{array}$ & 693 & 1 & 1 & 1 & 0.61 & 0.24 & 0 & 0 & 0.94 \\
\hline $\begin{array}{l}\text { Mannheim, } \\
\text { Germany }\end{array}$ & $\begin{array}{l}8.6^{\circ} / \\
49.5^{\circ}\end{array}$ & 641 & 1 & 1 & 1 & 0.56 & 0.47 & 0.29 & 0 & 0.94 \\
\hline $\begin{array}{l}\text { Debrecen, } \\
\text { Hungary }\end{array}$ & $\begin{array}{r}21.6^{\circ} / \\
47.6^{\circ}\end{array}$ & 563 & 1 & 1 & 1 & 0.56 & 0.39 & 0 & 0 & 0.12 \\
\hline $\begin{array}{l}\text { Clermont- } \\
\text { Ferrand, } \\
\text { France }\end{array}$ & $\begin{array}{l}3.1^{\circ} \% \\
45.8^{\circ}\end{array}$ & 600 & 1 & 1 & 1 & 0.56 & 0.31 & 0 & 0.47 & 0.47 \\
\hline $\begin{array}{l}\text { Montagnano, } \\
\text { Italy }\end{array}$ & $\begin{array}{r}11.8^{\circ} / \\
43.3^{\circ}\end{array}$ & 752 & 1 & 1 & 1 & 0.56 & 0.11 & 0 & 0.66 & 0.25 \\
\hline Seville, Spain & $\begin{array}{r}-5.9^{\circ} / \\
37.4^{\circ}\end{array}$ & 542 & 1 & 1 & 1 & 0.56 & 0.05 & 0 & 0.54 & 0.63 \\
\hline
\end{tabular}

conditions in Poland. At the same time, Semenov et al. (2014) noticed that the trait that requires selection based on specific root parameters is difficult to examine. Model results show that environment-specific variety improvement based on weather probability scenarios can be a plant breeding-supporting method in the future (Vadez et al. 2013b)

\section{Conclusions}

Presently, agriculture is at its turning point (Anioł 2010). Prior to marker-assisted selection and genetic modifications, plant ideotypes have to be precisely defined (Araus and Cairns 2014). Although modeling of crop ideotypes for future decades in the prospect of climate change is a form of setting priorities, only the consensus between theoretical results and conventional breeding, extremely successful in improving plant performance under water deficit, will allow to create directions for plant breeding (Tardieu 2012).

There is a need for critical reference of practical breeding to theoretical models as well. Results of literature searches indicate that the Rothamsted Research collects data on the variability of traits in accordance with the priorities generated by the Sirius model (Driever et al. 2014; Khattak et al. 2014). In Poland, the cereal ideotypes are defined on the basis of traits: morphological (plant height, ear length, size of the flag leaf) and phenological (date of commencement of vegetation after winter dormancy, terms of earing and ripening). Disease resistance is also an important trait. On the basis of breeding evaluation, a modern cereal ideotype should be characterized by: a later heading for the reason of longer period to form more ear buds; a fast grain filling, which is especially important during drought period; a fast transport of assimilates to the grain; short and rigid stems, which prevents lodging in dense sowing; high mass of 1000 grains and high density in standard mass per storage volume; sprouting resistance and tolerance to plant diseases. An interdisciplinary, critical discussion about the results of modeling is needed from the perspective of practical breeding.

These priorities do not directly take into account the aspects related to the efficiency of water use by crops (Gago et al. 2014; Tallec et al. 2013). Judging by the rapidly growing number of publications, the problem is increasingly discussed by scientists working in the field of 
plant breeding (Harb et al. 2010). In the reality of agriculture and science funding in Poland, it can be anticipated that development and implementation of screening tools for abiotic stresses tolerance and/or avoidance as well as efficient use of water by crop plants will be based on hyperspectral analysis (Costa et al. 2013; Gnyp et al. 2014; Liu et al. 2010). The essential issues of crop improvement can be specified and resolved as a result of close cooperation between scientists and breeders (Starck 2009).

Author contribution statement KR authored the theoretical discussion supported by ZN's practical perspective.

Acknowledgments The work was funded by the National Science Centre Poland with grant \# 304267540.

Open Access This article is distributed under the terms of the Creative Commons Attribution 4.0 International License (http:// creativecommons.org/licenses/by/4.0/), which permits unrestricted use, distribution, and reproduction in any medium, provided you give appropriate credit to the original author(s) and the source, provide a link to the Creative Commons license, and indicate if changes were made.

\section{References}

Akkaya A, Dokuyucu T, Kara R, Akcura M (2006) Harmonization ratio of post- to pre-anthesis durations by thermal times for durum wheat cultivars in a Mediterranean environment. Eur J Agron 24:404-408. doi:10.1016/j.eja.2005.10.005

Amani I, Fischer RA, Reynolds MP (1996) Canopy temperature depression association with yield of irrigated spring wheat cultivars in a hot climate. J Agron Crop Sci 176:119-129. doi:10. 1111/j.1439-037X.1996.tb00454.x

Anioł A (2010) The impact of biotechnology and globalization processes on plant breeding and its R\&D component (in Polish with English Summary and Legends). Biul IHAR 256:3-13. http://biblioteka.ihar.edu.pl/biuletyn_ihar.php?field[slowa_kluc zowe $]=\&$ field $[$ autor $]=\& \mathrm{id}=51 \& \mathrm{idd}=1089 \&$ podzial_id=1\&pod zial_idd=\#lib

Anonymous (2014) Crop Modeling Team Highlights web-page http:// www.agmip.org/wp-content/uploads/2012/11/Crop_Modeling _ 2011-2012_Highlights-web.pdf last modified 16 May 2014 05:53:53. Accessed 29 Sept 2014

Araus JL, Cairns JE (2014) Field high-throughput phenotyping: the new crop breeding frontier. Trends Plant Sci 19:52-61. doi:10. 1111/j.1744-7909.2012.01116.x

Asseng S, Ewert F, Rosenzweig C, Jones JW, Hatfield JL, Ruane AC, Boote KJ, Thorburn PJ, Rotter RP, Cammarano D, Brisson N, Basso B, Martre P, Aggarwal PK, Angulo C, Bertuzzi P, Biernath C, Challinor AJ, Doltra J, Gayler S, Goldberg R, Grant R, Heng L, Hooker J, Hunt LA, Ingwersen J, Izaurralde RC, Kersebaum KC, Muller C, Naresh Kumar S, Nendel C, O'Leary G, Olesen JE, Osborne TM, Palosuo T, Priesack E, Ripoche D, Semenov MA, Shcherbak I, Steduto P, Stockle C, Stratonovitch P, Streck T, Supit I, Tao F, Travasso M, Waha K, Wallach D, White JW, Williams JR, Wolf J (2013) Uncertainty in simulating wheat yields under climate change. Nat Clim Change 3:827-832. doi:10.1038/nclimate1916

Atkin OK, Macherel D (2009) The crucial role of plant mitochondria in orchestrating drought tolerance. Ann Bot 103:58-597. doi:10. 1093/aob/mcn094
Atkinson NJ, Urwin PE (2012) The interaction of plant biotic and abiotic stresses: from genes to the field. J Exp Bot 63:3523-3544. doi:10.1093/jxb/ers 100

Bacławska-Krzemińska Z (1973) Influence of light, water deficit and age of plant on photosynthesis and air passage capacity in leaves of Brassica oleracea L. var. capitata alba v. Ditmarska. Plant Breed Seed Sci 17:303-328

Belko N, Zaman-Allah M, Diop NN, Cisse N, Zombre G, Ehlers JD, Vadez V (2013) Restriction of transpiration rate under high vapour pressure deficit and non-limiting water conditions is important for terminal drought tolerance in cowpea. Plant Biol 15:304-316. doi:10.1111/j.1438-8677.2012.00642.x

Bhatnagar-Mathur P, Vadez V, Sharma K (2008) Transgenic approaches for abiotic stress tolerance in plants: retrospect and prospects. Plant Cell Rep 27:411-424. doi:10.1007/s00299-0070474-9

Blum A (2009) Effective use of water (EUW) and not water-use efficiency (WUE) is the target of crop yield improvement under drought stress. Field Crop Res 112:119-123. doi:10.1016/j.fcr. 2009.03.009

Blum A (2011a) Drought resistance-is it really a complex trait? Funct Plant Biol 38:753-757. doi:10.1071/FP11101

Blum A (2011b) Plant breeding for water-limited environments. Springer, New York

Blum A, Mayer J, Gozlan G (1982) Infrared thermal sensing of plant canopies as a screening technique for dehydration avoidance in wheat. Field Crops Res 5:137-146. doi:10.1016/03784290(82)90014-4

Borlaug N (2007) Sixty-two years of fighting hunger: personal recollections. Euphytica 157:287-297. doi:10.1007/s10681-0079480-9

Brooks RJ, Semenov MA, Jamieson PD (2001) Simplifying Sirius: sensitivity analysis and development of a meta-model for wheat yield prediction. Eur J Agron 14:43-60. doi:10.1016/S11610301(00)00089-7

Cabrera-Bosquet L, Crossa J, von Zitzewitz J, Serret MD, Araus JL (2012) High-throughput phenotyping and genomic selection: the frontiers of crop breeding converge. J Integr Plant Biol 54:312-320. doi:10.1111/j.1744-7909.2012.01116.x

Caramelo JJ, Iusem ND (2009) When cells lose water: lessons from biophysics and molecular biology. Prog Biophys Mol Biol 99:1-6. doi:10.1016/j.pbiomolbio.2008.10.001

Chern C-G, Fan M-J, Huang S-C, Yu S-M, Wei F-J, Wu C-C, Trisiriroj A, Lai M-H, Chen S, Hsing Y-I (2011) Methods for rice phenomics studies. In: Pereira A (ed) Plant reverse genetics, vol 678. Springer, pp 129-138. http://www.google.com/url?sa= $\mathrm{t} \& \mathrm{rct}=\mathrm{j} \& \mathrm{q}=\& \mathrm{esrc}=\mathrm{s} \&$ source $=$ web $\& \mathrm{~cd}=1 \&$ ved $=0 \mathrm{CB} 4 \mathrm{QFjAA}$ \&url=http $\% 3 \mathrm{~A} \% 2 \mathrm{~F} \% 2 \mathrm{Fwww}$. researchgate.net $\% 2 \mathrm{Fprofile} \% 2 \mathrm{FY}$ ue-ie_Hsing\%2Fpublication $\% 2 F 47371368$ Methods_for_rice phenomics_studies\%2Flinks\%2F0a85e5366f2f99023a000000. pdf\&ei=C5syVabYO8HasgHplILACg\&usg=AFQjCNHdukUdN GhXgdl-2bY0mTPZGMJTqQ\&bvm=bv.91071109,d.bGg

Christopher JT, Manschadi AM, Hammer GL, Borrell AK (2008) Developmental and physiological traits associated with high yield and stay-green phenotype in wheat. Aust J Agric Res 59:354-364. doi:10.1071/AR07193

Claeys H, Van Landeghem S, Dubois M, Maleux K, Inzé D (2014) What is stress? Dose-response effects in commonly used in vitro stress assays. Plant Physiol 165:519-527. doi:10.1104/pp.113.234641

Comstock JP (2002) Hydraulic and chemical signaling in the control of stomatal conductance and transpiration. J Exp Bot 53:195-200. doi:10.1093/jexbot/53.367.195

Costa JM, Grant OM, Chaves MM (2013) Thermography to explore plant-environment interactions. J Exp Bot 64:3937-3949. doi: $10.1093 /$ jxb/ert029 
Craufurd PQ, Vadez V, Jagadish SVK, Prasad PVV, Zaman-Allah M (2013) Crop science experiments designed to inform crop modelling. Agric For Meteorol 170:8-18. doi:10.1016/j.agrfor met.2011.09.003

Cutler SR, Rodriguez PL, Finkelstein RR, Abrams SR (2010) Abscisic acid: emergence of a core signaling network. Annu Rev Plant Biol 61:651-679. doi:10.1146/annurev-arplant042809-112122

Doroszewski A, Jadczyszyn J, Kozyra J, Pudełko R, Stuczyński T, Mizak K, Łopatka A, Koza P, Górski T, Wróblewska E (2012) Fundamentals of the agricultural drought monitoring system. Woda-Środowisko-Obszary Wiejskie 12: 77-91 (in Polish with English Summary). http://www.itp.edu.pl/oferta/wydawnictwo/ woda/zeszyt_38_2012/artykuly/Doroszewski\%20i\%20in.pdf

Driever SM, Lawson T, Andralojc PJ, Raines CA, Parry MAJ (2014) Natural variation in photosynthetic capacity, growth, and yield in 64 field-grown wheat genotypes. J Exp Bot 65:4959-4973. doi:10.1093/jxb/eru253

Du T, Kang S, Sun J, Zhang X, Zhang J (2009) An improved water use efficiency of cereals under temporal and spatial deficit irrigation in north China. Agric Water Manag 97:66-74. doi:10. 1016/j.agwat.2009.08.011

Easterling DR, Horton B, Jones PD, Peterson TC, Karl TR, Parker DE, Salinger MJ, Razuvayev V, Plummer N, Jamason P, Folland CK (1997) Maximum and minimum temperature trends for the globe. Science 277:364-367. doi:10.1126/science.277.5324.364

Easterling DR, Evans JL, Groisman PY, Karl TR, Kunkel KE, Ambenje P (2000) Observed variability and trends in extreme climate events: a brief review. Bull Am Meteorol Soc 81:417-425. doi:10.1175/1520-0477(2000)081!0417

Eyal Z, Blum A (1989) Canopy temperature as a correlative measure for asscessing host response to Septoria tritici bloch of wheat. Plant Dis 73:468-471. doi:10.1094/PD-73-0468

FAO, Food and Agriculture Organization (2003) Review of world water resources by country. Water reports vol 23. FAO, Rome. ISBN 92-5-104899-1. http://www.fao.org/docrep/005/y4473e/ y4473e00.HTM

Feng B, Yu H, Hu Y, Gao X, Gao J, Gao D, Zhang S (2009) The physiological characteristics of the low canopy temperature wheat (Triticum aestivum L.) genotypes under simulated drought condition. Acta Physiol Plant 31:1229-1235. doi:10.1007/ s11738-009-0358-4

Fischer RA, Rees D, Sayre KD, Lu Z-M, Condon AG, Saavedra AL (1998) Wheat yield progress associated with higher stomatal conductance and photosynthetic rate, and cooler canopies. Crop Sci 38:1467-1475. doi:10.2135/cropsci1998.0011183X0038000 $60011 \mathrm{x}$

Fish DA, Earl HJ (2009) Water-use efficiency is negatively correlated with leaf epidermal conductance in cotton (Gossypium spp.). Crop Sci 49:1409-1415. doi:10.2135/cropsci2008.08.0490

Fleury D, Jefferies S, Kuchel H, Langridge P (2010) Genetic and genomic tools to improve drought tolerance in wheat. J Exp Bot 61:3211-3222. doi:10.1093/jxb/erq152

Foyer C, Noctor G (2009) Redox regulation in photosynthetic organisms: signaling, acclimation, and practical implications. Antioxid Redox Signal 11:861-905. doi:10.1089/ars.2008.2177

Gago J, Douthe C, Florez-Sarasa I, Escalona JM, Galmes J, Fernie AR, Flexas J, Medrano H (2014) Opportunities for improving leaf water use efficiency under climate change conditions. Plant Sci 226:108-119. doi:10.1016/j.plantsci.2014.04.007

Gassman PW, Williams JR, Benson VW, Izaurralde RC, Hauck LM, Jones CA, Atwood JD, Kiniry JR, Flowers JD (2004) Historical development and applications of the EPIC and APEX models. ASAE/CSAE Annual International Meeting Ottawa, Canada. Meeting Paper No. 042097. http://www.card.iastate.edu/publica tions/synopsis.aspx?id=763
Gewin V (2010) Food: an underground revolution. Nature 466:552-553. doi:10.1038/466552a

GUS, Główny Urząd Statystyczny (2013) Produkcja Upraw Rolniczych i Ogrodniczych w 2012 r. Materiały źródłowe. ISSN 1509-7099. http://stat.gov.pl/cps/rde/xbcr/gus/RL_produkcja_ upraw_roln_i_ogrod_w_2012.pdf

Gnyp ML, Bareth G, Li F, Lenz-Wiedemann VIS, Koppe W, Miao Y, Hennig SD, Jia L, Laudien R, Chen X, Zhang F (2014) Development and implementation of a multiscale biomass model using hyperspectral vegetation indices for winter wheat in the North China Plain. Int J Appl Earth Observ Geoinf 33:232-242. doi:10.1016/j.jag.2014.05.006

Gosal SS, Wani SH, Kang MS (2009) Biotechnology and drought tolerance. J Crop Improv 23:19-54. doi:10.1080/15427520802418251

Granier C, Aguirrezabal L, Chenu K, Cookson SJ, Dauzat M, Hamard P, Thioux J-J, Rolland G, Bouchier-Combaud S, Lebaudy A, Muller B, Simonneau T, Tardieu F (2006) PHENOPSIS, an automated platform for reproducible phenotyping of plant responses to soil water deficit in Arabidopsis thaliana permitted the identification of an accession with low sensitivity to soil water deficit. New Phytol 169:623-635. doi:10.1111/j.14698137.2005.01609.x

Grudkowska M, Zagdańska B (2004) Multifunctional role of plant cysteine proteinases. Acta Biochim Pol 51:609-624

Hammer G, Chapman S, Ev Oosterom, Podlich D (2004) Trait physiology and crop modelling to link phenotypic complexity to underlying genetic systems. Aust J Agric Res 56:947-960. doi:10.1071/AR05157

Hammer GL, van Oosterom E, McLean G, Chapman SC, Broad I, Harland P, Muchow RC (2010) Adapting APSIM to model the physiology and genetics of complex adaptive traits in field crops. J Exp Bot 61:2185-2202. doi:10.1093/jxb/erq095

Harb A, Krishnan A, Ambavaram MMR, Pereira A (2010) Molecular and physiological analysis of drought stress in Arabidopsis reveals early responses leading to acclimation in plant growth. Plant Physiol 154:1254-1271. doi:10.1104/pp.110.161752

Houle D, Govindaraju DR, Omholt S (2010) Phenomics: the next challenge. Nat Rev Genet 11:855-865. doi:10.1038/nrg2897

$\mathrm{Hu} \mathrm{H}$, Xiong L (2014) Genetic engineering and breeding of droughtresistant crops. Ann Rev Plant Biol 65:715-741. doi:10.1146/ annurev-arplant-050213-040000

Hussain SS, Iqbal MT, Arif MA, Amjad M (2011) Beyond osmolytes and transcription factors: drought tolerance in plants via protective proteins and aquaporins. Biol Plant 55:401-413. doi:10.1007/s10535-011-0091-x

Iturriaga G (2008) The LEA proteins and trehalose loving couple: a step forward in anhydrobiotic engineering. Biochem J 410:e1e2. doi:10.1042/BJ20071633

Iturriaga G, Suárez R, Nova-Franco B (2009) Trehalose metabolism: from osmoprotection to signaling. Int J Mol Sci 10:3793-3810. doi:10.3390/ijms 10093793

Izanloo A, Condon AG, Langridge P, Tester M, Schnurbusch T (2008) Different mechanisms of adaptation to cyclic water stress in two South Australian bread wheat cultivars. J Exp Bot 59:3327-3346. doi:10.1093/jxb/ern199

Jaggard KW, Qi A, Ober ES (2010) Possible changes to arable crop yields by 2050. Philos T R Soc B 365:2835-2851. doi:10.1098/ rstb.2010.0153

Jaleel CA, Manivannan P, Wahid A, Farooq R, Somasundaram R, Panneerselvam R (2009) Drought stress in plants: a review on morphological characteristics and pigments composition. Int $\mathrm{J}$ Agric Biol 11:100-105

Jamieson PD, Semenov M, Brooking I, Fracois G (1998) Sirius: a mechanistic model of wheat response to environmental variation. Eur J Agron 8:161-179. http://www.sciencedirect.com/science/ article/pii/S1161030100000897 
Jogaiah S, Govind SR, Tran LSP (2013) Systems biology-based approaches toward understanding drought tolerance in food crops. Crit Rev Biotechnol 33:23-39. doi:10.3109/07388551. 2012.659174

Jordan DR, Tao Y, Godwin ID, Henzell RG, Cooper M, McIntyre CL (2003) Prediction of hybrid performance in grain sorghum using RFLP markers. Theor Appl Genet 106:559-567. doi:10.1007/ s00122-012-1905-8

Kacperska A (2002) Reakcje roślin na abiotyczne czynniki stresowe. In: Kopcewicz J, Lewak S (eds) Fizjologia roślin, 2nd edn. PWN, Warszawa, pp 612-678. ISBN 83-01-13753-3

Kemanian AR, Stöckle CO, Huggins DR (2005) Transpiration-use efficiency of barley. Agr Forest Meteorol 130:1-11. doi:10.1016/ j.agrformet.2005.01.003

Khattak GSS, Parry MAJ, Andralojc J, Saeed I, Shams Ur R (2014) Evaluation of diverse wheat genotypes for potential biomass production through physiological parameters at seedling stage under controlled environment. Pak J Bot 46:181-184. https:// inis.iaea.org/search/search.aspx?orig_q=RN:45109105

Kholová J, Hash CT, Kakkera A, Kocova M, Vadez V (2010a) Constitutive water-conserving mechanisms are correlated with the terminal drought tolerance of pearl millet (Pennisetum glaucum L.). J Exp Bot 61:369-377. doi:10.1093/jxb/erp314

Kholová J, Hash CT, Kumar PL, Yadav RS, Kocova M, Vadez V (2010b) Terminal drought-tolerant pearl millet [Pennisetum glaucum (L.) R. Br.] have high leaf ABA and limit transpiration at high vapour pressure deficit. J Exp Bot 61:1431-1440. doi:10. 1093/jxb/erq013

Kholová J, McLean G, Vadez V, Craufurd P, Hammer GL (2013) Drought stress characterization of post-rainy season (rabi) sorghum in India. Field Crops Res 141:38-46. doi:10.1016/j. fcr.2012.10.020

Kholová J, Murugesan T, Kaliamoorthy S, Malayee S, Baddam R, Hammer GL, McLean G, Deshpande S, Hash CT, Craufurd PQ, Vadez V (2014) Modelling the effect of plant water use traits on yield and stay-green expression in sorghum. Funct Plant Biol 41:1019-1034. doi:10.1071/FP13355

Kirkegaard JA, Lilley JM, Howe GN, Graham JM (2007) Impact of subsoil water use on wheat yield. Aust J Agric Res 58:303-315. doi:10.1071/AR06285

Knight S, Kightley S, Bingham I, Hoad S, Lang B, Philpott H, Stobart R, Thomas J, Barnes A, Ball B (2012) Desk study to evaluate contributory causes of the current 'yield plateau' in wheat and oilseed rape. HGCA Report No 502: p 225. http://archive.hgca.com/ document.aspx?fn=load\&media_id=8278\&publicationId=9165

Koza JR, Keane MA, Streeter MJ (2003) Zastosowanie mechanizmów ewolucji w programowaniu komputerowym daje nowatorskie rezultaty. Świat Nauki 4(140):40-47

Łabędzki L (2006) Susze rolnicze. Zarys problematyki oraz metody monitorowania i klasyfikacji. Woda Środowisko Obszary Wiejskie 17: monografia

Labudda M, Azam FMS (2014) Glutathione-dependent responses of plants to drought: a review. Acta Soc Bot Pol 83:3-12

Levitt J (1972) Drought avoidance (Chapter 14). In: Levitt J (ed) Responses of plants to environmental stresses. Academic Press, New York, pp 353-378

Liu Z-Y, Wu H-F, Huang J-F (2010) Application of neural networks to discriminate fungal infection levels in rice panicles using hyperspectral reflectance and principal components analysis. Comput Electron Agric 72:99-106. doi:10.1016/j.compag.2010. 03.003

Lobell DB, Tebaldi C (2014) Getting caught with our plants down: The risks of a global crop yield slowdown from climate trends in the next two decades. Environ Res Lett 9 (p 9). doi:10.1088/ $1748-9326 / 9 / 7 / 074003$
Lopes MS, Rebetzke GJ, Reynolds M (2014) Integration of phenotyping and genetic platforms for a better understanding of wheat performance under drought. J Exp Bot: first published online 22 Sept 2014. doi:10.1093/jxb/eru384

Lu ZM, Radin JW, Turcotte EL, Percy R, Zeiger E (1994) High yields in advanced lines of pima cotton are associated with higher stomatal conductance, reduced leaf area and lower leaf temperature. Physiol Plant 92:266-272

Mackay I, Horwell A, Garner J, White J, McKee J, Philpott H (2011) Re-analyses of the historical series of UK variety trials to quantify the contributions of genetic and environmental factors to trends and variability in yield over time. Theor Appl Gen 122:225-238. doi:10.1007/s00122-010-1438-y

Manschadi AM, Christopher J, Devoil P, Hammer GL (2006) The role of root architectural traits in adaptation of wheat to waterlimited environments. Funct Plant Biol 33:823-837. doi:10. 1071/FP06055

Marcińska I, Czyczyło-Mysza I, Skrzypek E, Filek M, Grzesiak S, Grzesiak M, Janowiak F, Hura T, Dziurka M, Dziurka K, Nowakowska A, Quarrie S (2013) Impact of osmotic stress on physiological and biochemical characteristics in drought-susceptible and drought-resistant wheat genotypes. Acta Physiol Plant 35:451-461. doi:10.1007/s11738-012-1088-6

Maseda PH, Ferniez RJ (2006) Stay wet or else: three ways in which plants can adjust hydraulically to their environment. J Exp Bot 57:3963-3977. doi:10.1093/jxb/er1127

McMaster GS (2005) Phytomers, phyllochrons, phenology and temperate cereal development. J Agric Sci 143:137-150. doi:10.1017/S0021859605005083

Meehl GA, Covey C, Taylor KE, Delworth T, Stouffer RJ, Latif M, McAvaney B, Mitchell JFB (2007) The WCRP CMIP3 multimodel dataset: a new era in climate change research. Bull Am Meteorol Soc 88:1383-1394. doi:10.1175/BAMS-88-9-1383

Messina CD, Podlich D, Dong Z, Samples M, Cooper M (2011) Yield-trait performance landscapes: from theory to application in breeding maize for drought tolerance. J Exp Bot 62:855-868. doi:10.1093/jxb/erq329

Miller G, Suzuki N, Ciftci-Yilmaz S, Mittler R (2010) Reactive oxygen species homeostasis and signalling during drought and salinity stresses. Plant Cell Environ 33:453-467. doi:10.1111/j. 1365-3040.2009.02041.x

Mott KA (2007) Leaf hydraulic conductivity and stomatal responses to humidity in amphistomatous leaves. Plant Cell Environ 30:1444-1449. doi:10.1111/j.1365-3040.2007.01720.x

Oleksiak T (2013) The use of certified seed and the yield of winter cereals (in Polish with English Summary and Legends). Biul IHAR 268:87-99. http://biblioteka.ihar.edu.pl/biuletyn_ihar. php?id=62\&field[autor] $=$ Oleksiak\&field[slowa_kluczowe] $=\&$ po dzial_id=\#lib

Pantin F, Monnet F, Jannaud D, Costa JM, Renaud J, Muller B, Simonneau T, Genty B (2013) The dual effect of abscisic acid on stomata. New Phytol 197:65-72. doi:10.1111/nph.12013

Passioura JB (1996) Simulation models: science, snake oil, education, or engineering? Agron J 88:690-694. doi:10.2134/agronj1996. $00021962008800050002 x$

Passioura JB (2012) Phenotyping for drought tolerance in grain crops: when is it useful to breeders? Funct Plant Biol 39:851-859. doi:10.1071/FP12079

Pinheiro C, Chaves MM (2011) Photosynthesis and drought: can we make metabolic connections from available data? J Exp Bot 62:869-882. doi:10.1093/jxb/erq340

Pinter PJ Jr, Zipoli G, Reginato RJ, Jackson RD, Idso SB, Hohman JP (1990) Canopy temperature as an indicator of differential water use and yield performance among wheat cultivars. Agric Water Manage 18:35-48. doi:10.1016/0378-3774(90)90034-V 
Porter JR, Semenov MA (2005) Crop responses to climatic variation. Philos Trans R Soc B 360:2021-2035. doi:10.1098/rstb.2005. 1752

Reynolds M, Tuberosa R (2008) Translational research impacting on crop productivity in drought-prone environments. Curr Opin Plant Biol 11:171-179. doi:10.1016/j.pbi.2008.02.005

Richards RA (2006) Physiological traits used in the breeding of new cultivars for water-scarce environments. Agric Water Manage 80:197-211. doi:10.1016/j.agwat.2005.07.013

Richards RA, Rebetzke GJ, Watt M, Condon AG, Spielmeyer W, Dolferus R (2010) Breeding for improved water productivity in temperate cereals: phenotyping, quantitative trait loci, markers and the selection environment. Funct Plant Biol 37:85-97. doi:10.1071/FP09219

Ritchie JT, Singh U, Godwin DC, Bowen WT (1998) Soil water balance and plant water stress. In: Tsuji Y, Tsuji GY, Hoogenboom G, Thornton PK (eds) Understanding options for agricultural production. Kluwer Academic Publishers, Dordrecht, pp 83-102. ISBN 0-7923-4833-8

Rosenzweig C, Jones JW, Hatfield JL, Ruane AC, Boote KJ, Thorburn P, Antle JM, Nelson GC, Porter C, Janssen S, Asseng S, Basso B, Ewert F, Wallach D, Baigorria G, Winter JM (2013) The Agricultural Model Intercomparison and Improvement Project (AgMIP): protocols and pilot studies. Agric For Meteorol 170:166-182. doi:10.1016/j.agrformet.2012.09.011

Rosenzweig C, Elliott J, Deryng D, Ruane AC, Müller C, Arneth A, Boote KJ, Folberth C, Glotter M, Khabarov N, Neumann K, Piontek F, Pugh TAM, Schmid E, Stehfest E, Yang H, Jones JW (2014) Assessing agricultural risks of climate change in the 21st century in a global gridded crop model intercomparison. Proc Nat Acad Sci USA 111:3268-3273. doi:10.1073/pnas. 1222463110

Rybka K (2011) Tilling and fox-hunting: new methods for functional analysis of genes. Adv Cell Biol 3(1):165-180. doi:10.2478/ v10052-011-0001-6

Schoppach R, Sadok W (2012) Differential sensitivities of transpiration to evaporative demand and soil water deficit among wheat elite cultivars indicate different strategies for drought tolerance. Environ Exp Bot 84:1-10. doi:10.1016/j.envexpbot.2012.04.016

Semenov MA, Stratonovitch P (2013) Designing high-yielding wheat ideotypes for a changing climate. Food Energy Secur 2:185-196. doi:10.1002/fes3.34

Semenov MA, Stratonovitch P, Alghabari F, Gooding MJ (2014) Adapting wheat in Europe for climate change. J Cereal Sci 59:245-256. doi:10.1016/j.jcs.2014.01.006

Shimshi D, Ephrat J (1975) Stomatal behavior of wheat cultivars in relation to their transpiration, photosynthesis and yield. Agron $\mathrm{J}$ 67:326-331. doi:10.2134/agronj1975.00021962006700030011x

Shinozaki K, Yamaguchi-Shinozaki K (2007) Gene networks involved in drought stress response and tolerance. J Exp Bot 58:221-227. doi:10.1093/jxb/erl164

Sillmann J, Roeckner E (2008) Indices for extreme events in projections of anthropogenic climate change. Clim Change 86:83-104. doi:10.1007/s10584-007-9308-6

Starck Z (2009) Dystrybucja asymilatów kluczowym procesem determinującym plon. Post Nauk Roln 2(2009):51-69

Strebeyko P (1973) Theoretical principles of gas exchange in plants. Plant Breed Seed Sci 17:287-295

Tallec T, Béziat P, Jarosz N, Rivalland V, Ceschia E (2013) Crops' water use efficiencies in temperate climate: comparison of stand, ecosystem and agronomical approaches. Agric For Meteorol 168:69-81. doi:10.1016/j.agrformet.2012.07.008

Tardieu F (2010) Why work and discuss the basic principles of plant modelling 50 years after the first plant models? J Exp Bot 61:2039-2041. doi:10.1093/jxb/erq135
Tardieu F (2012) Any trait or trait-related allele can confer drought tolerance: just design the right drought scenario. J Exp Bot 63:25-31. doi:10.1093/jxb/err269

Thakur A (1991) Model: mechanistc vs. empirical. In: Rescigno A, Thakur A (eds) New trends in pharmacokinetics. Plenum Press, New York, pp 41-51

Tomassini L, Jacob D (2009) Spatial analysis of trends in extreme precipitation events in high-resolution climate model results and observations for Germany. J Geophys Res Atmos 114:D12113. doi:10.1029/2008jd010652

Trenberth KE, Dai A, Rasmussen RM, Parsons DB (2003) The changing character of precipitation. Bull Am Meteorol Soc 84:1205-1217. doi:10.1175/bams-84-9-1205

Vadez V, Rao S, Kholová J, Krishnamurthy L, Kashiwagi J, Ratnakumar P, Sharma K, Bhatnagar-Mathur P, Basu P (2008) Root research for drought tolerance in legumes: Quo vadis? J Food Legumes 21:77-85

Vadez V, Kholová J, Yadav R, Hash C (2013a) Small temporal differences in water uptake among varieties of pearl millet (Pennisetum glaucum L.) are critical for grain yield under terminal drought. Plant Soil 371:447-462. doi:10.1007/s11104013-1706-0

Vadez V, Kholová J, Zaman-Allah M, Belko N (2013b) Water: the most important 'molecular' component of water stress tolerance research. Funct Plant Biol 40:1310-1322. doi:10.1071/FP13149

Vadez V, Rao JS, Bhatnagar-Mathur P, Sharma KK (2013c) DREB1A promotes root development in deep soil layers and increases water extraction under water stress in groundnut. Plant Biol 15:45-52. doi:10.1111/j.1438-8677.2012.00588.x

Vadez V, Kholová J, Medina S, Kakkera A, Anderberg H (2014) Transpiration efficiency: new insights into an old story. J Exp Bot 65:6141-6153. http://jxb.oxfordjournals.org/content/65/21/ 6141

Wasson AP, Richards RA, Chatrath R, Misra SC, Prasad SVS, Rebetzke GJ, Kirkegaard JA, Christopher J, Watt M (2012) Traits and selection strategies to improve root systems and water uptake in water-limited wheat crops. J Exp Bot 63:3485-3498. doi:10.1093/jxb/ers111

White JW, Andrade-Sanchez P, Gore MA, Bronson KF, Coffelt TA, Conley MM, Feldmann KA, French AN, Heun JT, Hunsaker DJ, Jenks MA, Kimball BA, Roth RL, Strand RJ, Thorp KR, Wall GW, Wang G (2012) Field-based phenomics for plant genetics research. Field Crop Res 133:101-112. doi:10.1016/j.fcr.2012. 04.003

Wolf J, Evans L, Semenov M, Eckersten H, Iglesias A (1996) Comparison of wheat simulation models under climate change I. Model calibration and sensitivity analyses. Clim Res 7:253-279. doi: $10.3354 / \mathrm{cr} 007253$

Yang W, Duan L, Chen G, Xiong L, Liu Q (2013) Plant phenomics and high-throughput phenotyping: accelerating rice functional genomics using multidisciplinary technologies. Curr Opin Plant Biol 16:180-187. doi:10.1016/j.pbi.2013.03.005

Yonekura-Sakakibara K, Fukushima A, Saito K (2013) Transcriptome data modeling for targeted plant metabolic engineering. Curr Opin Biotechnol 24:285-290. doi:10.1016/j.copbio.2012.10.018

Zagdańska B (1997) Mechanizmy odporności zbóż na suszę glebową: metabolizm energetyczny pszenicy jarej w nabywaniu odporności. (in Polish with English Summary and Legends) Biul IHAR 203:41-55. doi:10.5586/asbp.1994.010

Zagdańska B, Kozdój J (1994) Water stress-induced changes in morphology and anatomy of flag leaf of spring wheat. Acta Soc Bot Pol 63:61-66. http://pbsociety.org.pl/journals/index.php/ asbp/article/view/asbp.1994.010

Zaman-Allah M, Jenkinson D, Vadez V (2011) Chickpea genotypes contrasting for seed yield under terminal drought stress in the 
field differ for traits related to the control of water use. Funct Plant Biol 38:270-281. doi:10.1071/FP10244

Zhang J, Dell B, Conocono E, Waters I, Setter T, Appels R (2009) Water deficits in wheat: fructan exohydrolase (1-FEH)mRNA expression and relationship to soluble carbohydrate concentrations in two varieties. New Phytol 181:843-850. doi:10.1111/j. 1469-8137.2008.02713.x

Zhou J, Wang J, Li X, Xia X-J, Zhou Y-H, Shi K, Chen Z, Yu J-Q (2014) $\mathrm{H}_{2} \mathrm{O}_{2}$ mediates the crosstalk of brassinosteroid and abscisic acid in tomato responses to heat and oxidative stresses. J Exp Bot 65:4371-4383. doi:10.1093/jxb/eru217

Zurek G (2004) The effect of natural and simulated drought on selected turf grass varieties. Biul IHAR 233:195-209 (in Polish with English Summary and Legends). http://biblioteka.ihar.edu. pl/biuletyn_ihar.php?field[slowa_kluczowe]=\&field[autor]=\&id= 28\&idd=241\&podzial_id=2\&podzial_idd= 